ORIENTAL JOURNAL OF CHEMISTRY

An International Open Access, Peer Reviewed Research Journal

www.orientjchem.org
ISSN: 0970-020 X

CODEN: OJCHEG

2019, Vol. 35, No.(1):

Pg. 481-484

Brief Communication

\title{
Synthesis and Antibacterial Screening of Novel Thiazolyl Pyrazole and Benzoxazole
}

\author{
VAIBHAV PRABHAKAR LANDAGE'1, DILIP RAOSAHEB THUBE* \\ and BHAUSAHEB KISAN KARALE ${ }^{2 *}$
}

\begin{abstract}
'Department of Chemistry, New Arts, Commerce and Science College, Parner,Ahmednagar-414302, India, ${ }^{2}$ Department of Chemistry, Radhabai Kale Mahila Mahavidyalaya, Ahmednagar-414001, India,

${ }^{*}$ Corresponding author Email: drthube@ rediffmail.com

http://dx.doi.org/10.13005/ojc/350164
\end{abstract}

Received: June 18, 2018; Accepted: December 10, 2018)

\begin{abstract}
A new series of (2-hydroxyphenyl)(1-(4-p-tolylthiazol-2-yl)-1H-pyrazol-4-yl)methanone 3a-g, 2[(E)-\{1-[4-(p-tolyl)-1, 3-thiazol-2-yl)]-1H-pyrazol-4-yl\} (hydroxyimino)methyl]phenol 4a-g and 2-(1-(4-p-tolylthiazol-2-yl)-1H-pyrazole-4-yl)benzo[d]oxazole 5a-g have been synthesised. These synthesised compounds have been characterised by the spectral, analytical data and scanned for their antibacterial activities.
\end{abstract}

Keywords: Thiazole,3-formylchromone, Pyrazole, Benzo[d]oxazole.

\section{INTRODUCTION}

The introduction of heterocyclic moieties found in molecules have advantage in drug discovery and development because of its broad range of biological activities. Thiazole and its derivatives show biological activities such as anti-inflammatory ${ }^{1}$, analgesic ${ }^{2}$, antimicrobial ${ }^{3,4}$, antioxidant ${ }^{5}$, antitumor ${ }^{6,7}$, anticonvulsant ${ }^{8}$. 3-formylchromone and its derivatives are known to associate in organic synthesis ${ }^{9}$ and showing biological activities include antitumor ${ }^{10}$, antibacterial ${ }^{10}$, antitubulin ${ }^{11}$, anti-helicobacter pylori ${ }^{12}$, antiallergic ${ }^{13}$, antioxidant ${ }^{14}$, topoisomerase I inhibitor ${ }^{15}$. Pyrazole containing heterocyclic molecules are associated with wide range of biological activities such as antimicrobial ${ }^{16}$, anticancer ${ }^{17}$, antifunga ${ }^{18}$, anti-inflammatory ${ }^{19}$, antitumor ${ }^{20}$, and anti-anxiety ${ }^{21}$. Benzoxazoles derivatives are found to be associated with anticancer ${ }^{22}$, antimicrobial ${ }^{23}$, HIV-1 reverse transcriptase Inhibitor Activity ${ }^{24}$, inhibitors of lysophosphatidic acid acyltransferase-beta ${ }^{25}$, anti-inflammatory ${ }^{26}$, analgesic ${ }^{26}$, antibacterial ${ }^{27}$, antifunga ${ }^{27}$, anticancer ${ }^{28}$ activities. As a part of our interest in heterocyclic molecules have a extensive variety of biological activities and that have been explored for developing pharmaceutically important molecules, we here in report the synthesis of a set of new series of thiazolyl pyrazoles and benzoxazoles and their antibacterial activities.

This is an Open Access article licensed under a Creative Commons license: Attribution 4.0 International (CC- BY). Published by Oriental Scientific Publishing Company @ 2018 


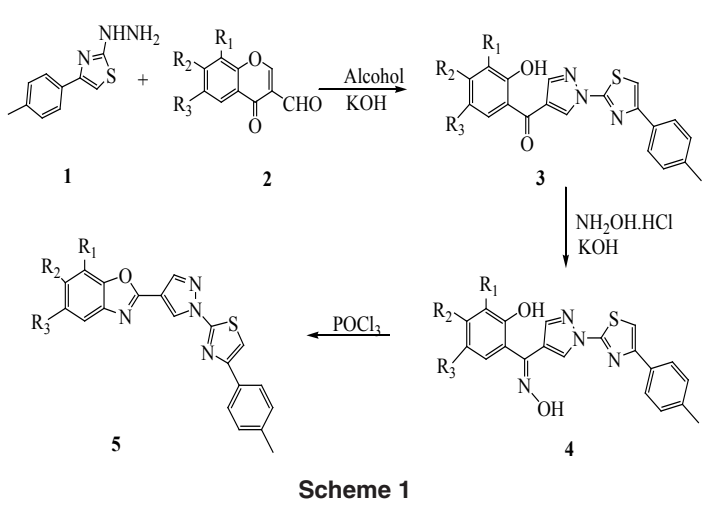

Table1: Physical characterisation of synthesised derivatives

\begin{tabular}{|c|c|c|c|c|c|}
\hline Derivatives & $\mathrm{R}_{1}$ & $\mathrm{R}_{2}$ & $\mathrm{R}_{3}$ & Yield(\%) & m.p. $\left({ }^{\circ} \mathrm{C}\right)$ \\
\hline $3 a$ & $\mathrm{H}$ & $\mathrm{H}$ & $\mathrm{Me}$ & 62 & $220-222$ \\
\hline $3 b$ & $\mathrm{H}$ & $\mathrm{H}$ & $\mathrm{Cl}$ & 64 & $230-232$ \\
\hline $3 c$ & $\mathrm{H}$ & $\mathrm{Me}$ & $\mathrm{H}$ & 60 & $236-238$ \\
\hline $3 d$ & $\mathrm{H}$ & $\mathrm{Me}$ & $\mathrm{Cl}$ & 68 & $204-206$ \\
\hline $3 e$ & $\mathrm{H}$ & $\mathrm{H}$ & $\mathrm{H}$ & 61 & $186-188$ \\
\hline $3 f$ & $\mathrm{H}$ & $\mathrm{H}$ & $\mathrm{Br}$ & 63 & $228-230$ \\
\hline $3 g$ & $\mathrm{Cl}$ & $\mathrm{H}$ & $\mathrm{Cl}$ & 65 & $210-212$ \\
\hline $4 a$ & $\mathrm{H}$ & $\mathrm{H}$ & $\mathrm{Me}$ & 58 & $232-234$ \\
\hline $4 b$ & $\mathrm{H}$ & $\mathrm{H}$ & $\mathrm{Cl}$ & 54 & $246-248$ \\
\hline $4 c$ & $\mathrm{H}$ & $\mathrm{Me}$ & $\mathrm{H}$ & 55 & $192-194$ \\
\hline $4 d$ & $\mathrm{H}$ & $\mathrm{Me}$ & $\mathrm{Cl}$ & 60 & $250-252$ \\
\hline $4 e$ & $\mathrm{H}$ & $\mathrm{H}$ & $\mathrm{H}$ & 52 & $214-216$ \\
\hline $4 f$ & $\mathrm{H}$ & $\mathrm{H}$ & $\mathrm{Br}$ & 56 & $206-208$ \\
\hline $4 \mathrm{~g}$ & $\mathrm{Cl}$ & $\mathrm{H}$ & $\mathrm{Cl}$ & 64 & $202-204$ \\
\hline $5 a$ & $\mathrm{H}$ & $\mathrm{H}$ & $\mathrm{Me}$ & 67 & $232-234$ \\
\hline $5 b$ & $\mathrm{H}$ & $\mathrm{H}$ & $\mathrm{Cl}$ & 54 & $196-198$ \\
\hline $5 c$ & $\mathrm{H}$ & $\mathrm{Me}$ & $\mathrm{H}$ & 55 & $202-204$ \\
\hline $5 d$ & $\mathrm{H}$ & $\mathrm{Me}$ & $\mathrm{Cl}$ & 53 & $240-242$ \\
\hline $5 e$ & $\mathrm{H}$ & $\mathrm{H}$ & $\mathrm{H}$ & 56 & $224-226$ \\
\hline $5 f$ & $\mathrm{H}$ & $\mathrm{H}$ & $\mathrm{Br}$ & 52 & $228-230$ \\
\hline $5 g$ & $\mathrm{Cl}$ & $\mathrm{H}$ & $\mathrm{Cl}$ & 54 & $244-246$ \\
\hline
\end{tabular}

\section{EXPERIMENTAL}

All the chemicals were from Sigma - Aldrich and used without any purification. Melting Points of synthesised compounds were taken in open capillary tubes and uncorrected. IR spectra were obtained in $\mathrm{KBr}$ pallet on a FT-IR spectrophotometer and Mass spectra were recorded on a Q-TOF MS ES-3.84e3. ${ }^{1} \mathrm{H}$ NMR spectra were recorded on Bruker Avance II $400 \mathrm{MHz}$ spectrometer with DMSO- $d_{6}$ as a solvent and using TMS as internal standard. Chemical shift

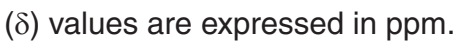

\section{(2-hydroxyphenyl)(1-(4-p-tolylthiazol-2-yl)-1 H- pyrazol-4-yl)methanone 3}

Equimolar mixture of thiazolyl hydrazine
$1(0.01 \mathrm{~mol})$ and 3-formyl chromone $2(0.01 \mathrm{~mol})$ in ethanol were refluxed for $45 \mathrm{~min}$, hydrazone derivative was obtained. Further, refluxing continues for $4-5 \mathrm{~h}$ by addition of $10 \mathrm{ml} 15 \%$ potassium hydroxide. After completion of reaction the content was cooled, poured into ice and then neutralised by using c. $\mathrm{HCl}$, solid pyrazolyl methanone derivative $3 \mathrm{a}$ produced. Then it was filtered and recrystallised from ethyl alcohol. The compounds 3b-g were synthesised by the same procedure.

3d. IR : $3105,1654,1610,1106 \mathrm{~cm}^{-1}$; Mass: $\mathrm{m} / \mathrm{z} 409.5\left(\mathrm{M}^{+}\right) ;{ }^{1} \mathrm{H}$ NMR (DMSO-d $)$ ): $\delta 2.37$ (s, 6H, Ar$\left.\mathrm{CH}_{3}\right), 6.99(\mathrm{~s}, 1 \mathrm{H}, \mathrm{Ar}-\mathrm{H}), 7.24$ (d, 2H, Ar-H), 7.60 (s, $1 \mathrm{H}, \mathrm{Ar}-\mathrm{H}), 7.81$ (s, $1 \mathrm{H}, \mathrm{Ar}-\mathrm{H}), 7.87(\mathrm{~d}, 2 \mathrm{H}, \mathrm{Ar}-\mathrm{H}), 8.23$ \& 8.96 (s, 2H, Pyrazole), 10.88 (s, 1H, Ar-OH); Elemental analysis- Calculated. $\mathrm{C}_{21} \mathrm{H}_{16} \mathrm{O}_{2} \mathrm{~N}_{3} \mathrm{~S} \mathrm{Cl}$ : C, 61.53; $\mathrm{H}, 3.93$; $\mathrm{N}, 10.25$. Found: C, $61.55 ; \mathrm{H}, 3.91 ; \mathrm{N}, 10.27 \%$.

\section{2[(E)-\{1-[4-(p-tolyl)-1, 3-thiazol-2-yl)]-1H-pyrazol- 4-yl\}(hydroxyimino)methyl]phenol 4}

To a solution of pyrazolyl methanone 3 (55 $\mathrm{mmol}$ ) in ethanol, $15 \mathrm{ml} 25 \%$ potassium hydroxide in water was added at about $0-4^{\circ} \mathrm{C}$ followed by hydroxylamine hydrochloride $(1.2 \mathrm{~mol})$ in heaps. Once the the addition was complete, continues stirring for $4 \mathrm{~h}$ at room temperature. After reaction completion, content was poured into ice water and neutralised with acetic acid, solid thiozole anchored pyrazolyl oxime $4 a$ separated. It was filtered and recrystallised from ethyl alcohol. The compounds $4 \mathrm{~b}-\mathrm{g}$ were synthesised by same procedure.

4d. IR : 3085, 1612, $1110 \mathrm{~cm}^{-1}$; Mass: $\mathrm{m} / \mathrm{z}$ $424.5\left(\mathrm{M}^{+}\right) ;{ }^{1} \mathrm{H}$ NMR $\left(\mathrm{DMSO}^{\left.-\mathrm{d}_{6}\right)}: \delta 2.33(\mathrm{~s}, 3 \mathrm{H}, \mathrm{Ar}-\right.$ $\mathrm{CH}_{3}$ ), 2.37 (s, 3H, Ar- $\left.\mathrm{CH}_{3}\right), 6.89$ ( $\left.\mathrm{s}, 1 \mathrm{H}, \mathrm{Ar}-\mathrm{H}\right), 7.20$ (s, 1H, Ar-H), 7.24 (d, 2H, Ar-H), 7.66 (s, 1H, Ar-H), $7.82(\mathrm{~m}, 3 \mathrm{H}, \mathrm{Ar}-\mathrm{H}), 8.88(\mathrm{~s}, 1 \mathrm{H}, \mathrm{Ar}-\mathrm{H}), 9.98(\mathrm{~s}, 1 \mathrm{H}$, $\mathrm{N}-\mathrm{OH}), 11.88$ (s, 1H, Ar-OH); Elemental analysisCalculated: $\mathrm{C}_{21} \mathrm{H}_{17} \mathrm{O}_{2} \mathrm{~N}_{4} \mathrm{SCl}$ : C, 59.36; $\mathrm{H}, 4.03 ; \mathrm{N}$, 13.19. Found: C, $59.35 ; \mathrm{H}, 4.05 ; \mathrm{N}, 13.17 \%$.

\section{2-(1-(4-p-tolylthiazol-2-yl)-1 H-pyrazole-4-yl) benzo[d]oxazole 5}

The thiozolyl oxime $4(5 \mathrm{mmol})$ in $5 \mathrm{ml} \mathrm{POCl}_{3}$ was taken in round bottom flask and refluxed for about 4 hour. After completion of reaction, cooled content was poured into ice and neutralised with $2 \%$ sodium hydroxide, solid gets separated. Then it was filtered and recrystallised from alcohol to afford oxazole $5 \mathrm{a}$. Compounds $5 \mathrm{~b}-\mathrm{g}$ was synthesised by same method. 
5d. IR : 1638, 1241, $1110 \mathrm{~cm}^{-1}$; Mass: $\mathrm{m} / \mathrm{z} 406.5\left(\mathrm{M}^{+}\right) ;{ }^{1} \mathrm{H}$ NMR (DMSO-d 6 ): $\delta 2.36$ (s, 3H, Ar- $\left.-\mathrm{CH}_{3}\right), 2.50\left(\mathrm{~s}, 3 \mathrm{H}, \mathrm{Ar}-\mathrm{CH}_{3}\right), 7.30(\mathrm{~d}, 2 \mathrm{H}, \mathrm{Ar}-\mathrm{H})$, $7.82(\mathrm{~s}, 1 \mathrm{H}, \mathrm{Ar}-\mathrm{H}), 7.89$ (s, $1 \mathrm{H}, \mathrm{Ar}-\mathrm{H}), 7.95$ (d, 2H, Ar-H), 7.98 (s, 1H, Ar-H), 8.58 \& $9.36(\mathrm{~s}, 2 \mathrm{H}, \mathrm{Ar}-\mathrm{H})$; Elemental analysis- Calculated: $\mathrm{C}_{21} \mathrm{H}_{15} \mathrm{ON}_{4} \mathrm{SCl}$ : C, 61.99; H, 3.72; N, 13.77. Found: C, 61.97; H, 3.74; $\mathrm{N}, 13.79 \%$.

\section{Antibacterial activity}

An antibacterial activity of synthesised compounds 3a-g, 4a-g and 5a-g were determined in vitro against two bacterial species $E$. coli and B. subtilis. By using agar well diffusion method, bacterial species were cultured on nutrient agar plates at $37^{\circ} \mathrm{C}$. Plate containing $20 \mathrm{ml}$ of nutrient agar was spread with $100 \mu \mathrm{l}$ of culture. The wells were made in the agar cork boarer of width of 6 $\mathrm{mm}$. The $100 \mu \mathrm{l}$ of test compounds were loaded in the well along with amphicilin as positive control and DMSO as vehicle control. The plates incubated at $37^{\circ} \mathrm{C}$ for 24 hours. Growth was evaluated visually by comparing a test plate with the control plates. The figures in Table-II indicates inhibition zone in $\mathrm{mm}$ and these are the mean of triplicate assays.

Table 2: Results of antibacterial activities of synthesised compounds

\begin{tabular}{|c|c|c|}
\hline \multirow{2}{*}{$\begin{array}{l}\text { Synthesised } \\
\text { compounds }\end{array}$} & \multicolumn{2}{|c|}{ Inhibition zone in $\mathrm{mm}$} \\
\hline & Bacillus subtilis & Escherichia coli \\
\hline $3 a$ & 11 & 13 \\
\hline $3 b$ & 9 & 14 \\
\hline $3 c$ & 11 & 15 \\
\hline $3 d$ & 12 & 15 \\
\hline $3 e$ & 15 & 16 \\
\hline $3 f$ & 13 & 10 \\
\hline $3 g$ & 12 & 12 \\
\hline $4 a$ & 13 & 14 \\
\hline $4 b$ & 10 & 15 \\
\hline $4 c$ & 12 & 14 \\
\hline $4 d$ & 11 & 16 \\
\hline $4 \mathrm{e}$ & 11 & 16 \\
\hline $4 f$ & 11 & 9 \\
\hline $4 g$ & 13 & 14 \\
\hline $5 a$ & 14 & 11 \\
\hline $5 b$ & 12 & 16 \\
\hline $5 c$ & 13 & 13 \\
\hline $5 d$ & 13 & 14 \\
\hline $5 e$ & 10 & 16 \\
\hline $5 f$ & 12 & 14 \\
\hline $5 g$ & 14 & 9 \\
\hline Amphicilin & 16 & 17 \\
\hline
\end{tabular}

\section{RESULT AND DISCUSSION}

Synthesised compounds 3a-g were obtained from the thiazole anchored molecule 1 and 3-formyl chromone 2. The yield of 3a-g compounds were in the range of $60-70 \%$. The FTIR spectra of 3d shown peak at 3105 and $1654 \mathrm{~cm}^{-1}$ indicated the presence of $\mathrm{Ar}-\mathrm{OH}$ and $\mathrm{C}=\mathrm{O}$ groups in molecule. Whereas, the NMR spectra of $3 d$ show the two singlets at $\delta 2.37 \& 10.88$ indicated the presence of $\mathrm{Ar}-\mathrm{CH}_{3}$ and $\mathrm{Ar}-\mathrm{OH}$. The compounds 4a-g were obtained from the compounds $3 \mathrm{a}-\mathrm{g}$ and hydroxylamine hydrochloride by stirring at room temperature, practical yield of $4 \mathrm{a}-\mathrm{g}$ compounds were in the range of $55-65 \%$. From the FTIR spectra of $4 \mathrm{~d}$, the appearance of peak at $3085 \mathrm{~cm}^{-1}$ indicated the presence of $\mathrm{Ar}-\mathrm{OH}$ and the disappearance of peak at $1654 \mathrm{~cm}^{-1}$ shown the absence of $\mathrm{C}=\mathrm{O}$ group. The NMR spectra of $4 \mathrm{~d}$ shown one singlet at $\delta 9.98$ indicated the presence of $-\mathrm{OH}$ group of oxime. The compounds 5a-g were obtained from the refluxing the compounds $4 \mathrm{a}-\mathrm{g}$ in $\mathrm{POCl}_{3}$, yield in the range of $50-60 \%$. The disappearance of IR peak at $3085 \mathrm{~cm}^{-1}$ shown the absence of $\mathrm{Ar}-\mathrm{OH}$ in $5 \mathrm{~d}$. In the NMR spectra of $5 \mathrm{~d}$, absence of two singlet at $\delta 9.98$ and 11.88 of $\mathrm{N}-\mathrm{OH} \& \mathrm{Ar}-\mathrm{OH}$, confirmed the formation of compound $5 \mathrm{~d}$. Mass spectroscopy also supported for the formation of 3a-g, 4a-g and 5a-g compounds. Physical characterised data of synthesised compounds are given in the Table-1. The antibacterial activities of synthesised compounds are summarised in the Table-2. The figures indicate the zone of inhibition in $\mathrm{mm}$. From the results it is apparent that among synthesised compounds $3 \mathrm{e}, 4 \mathrm{~g}$ and $5 \mathrm{~b}$ have shown good antibacterial activities.

\section{ACKNOWLEDGEMENT}

The authors are thankful to the P.G. Department of Chemistry, Radhabai Kale Mahila Mahavidyalaya, Ahmednagar and Department of Chemistry, New Arts, Commerce and Science College, Parner, Ahmednagar for providing chemicals. Authors are also thankful to the Management of Anekant Education Society, Baramati, Pune for providing necessary research facilities moreover to the Directors, SAIF and CIL, Panjab University, Chandigarh for providing the spectral and analytical data. 


\section{REFERENCES}

1. Sharma, R. N.; Xavier, F. P.; Vasu, K. K.; Chaturvedi, S. C. \& Pancholi, S. S. J. Enz. Inhib. Med. Chem., 2009, 24, 890.

2. Kalkhambkar, R.J.; Kulkarni, G. M.; Shivkumar, H. \& Nagendra Rao, R. Eur. J. Med. Chem., 2007, 42, 1272.

3. Karegoudar, P.; Karthikeyan, M. S.; Prasad, D. J.; Mahalinga, M.; Holla, B. S. \& Kumari, N. S. Eur. J. Med. Chem., 2008, 43, 261.

4. Mhaske, P. C.; Vadgaonkar, K. S.; Jadhav, R. P. \& Bobade, V. D. J. Korean Chem. Soc., 2011, 55(5), 882.

5. Jaishree, V.; Ramdas, N.; Sachin, J. \& Ramesh, B. J. Saudi Chem. Soc., 2012, 16, 371.

6. Bradshaw, T. D. \& Westwell, A. D. Curr. Med. Chem., 2004, 11, 1009.

7. Hutchinson, I.; Jennings, S. A.; Vishnuvajjala, B. R.; Westwell, A. D. \& Stevens, M.F.G. J. Med. Chem., 2002, 45, 744.

8. Hays, S. J.; Rice, M. J.; Ortwine, D. F.; Johnson, G.; Schwarz, R. D.; Boyd, D. K.; Copeland, L. F.; Vartanian, M. G. \& Boxer, P. A. J. Pharm. Sci., 1994, 83, 1425.

9. Sabitha, G. Aldrichimica Acta., 1996, 29, 15.

10. Nawrot-Modranka, J.; Nawrot, E. \& Graczyk, J. Eur. J. Med. Chem., 2006, 41, 1301.

11. Wang, B.; Yang, Z-Y. \& Li, T. Bioorg. Med. Chem., 2006, 14, 6012.

12. Masami, K.; Toru, T.; Hiroyuki, K.; Satoru, T.; Hideki, N. \& Hiroshi, S. In. Vivo., 2007, 21, 829.

13. Fitzmaerice, C.\& Wragg, A.H. Chem. Abstr., 1966, 65, 3444.

14. Lee, H.; Lee, K.; Jung, J. K.; Cho, J. E. \& Theodorakis, E. A. Bioorg. Med. Chem. Lett., 2005, 15, 2745.

15. Boege, F.; Straub, T.; Kehr, A.; Boesenberg,
C.; Christiansen, K,; Andersen, A.; Jakob, F. \& Köhrle, J. J. Bio. Chem., 1996, 271, 2262.

16. Karale, B. K.; Pawar, P. Y.; Gadakh, A. V.; Akolkar, H. N.; \& Rindhe, S. S. Indian J. Het. Chem., 2014, 23(3), 283.

17. Amandeep, K.; Rashmi, A. \& Gill, N. S. Int. J. Nat. Prod. Sci., 2012, 1, 247.

18. Zhao, P. L.; Wang, F. \& Zhang, M. Z. J. Agreec. Foodchem., 2008, 56, 1076.

19. Benard, M.; Hulley, E.; Molenda, H. \& Stochla, K. Pharmazie., 1986, 41, 560.

20. Park, H. J.; Lee, K.; Park, S. J.; Ahn, B.; Lee, J. C; Cho, S. Y. \& Lee, K. I. Bioorg. Med. Chem. Lett., 2005, 15, 3307.

21. Wastrow, D. J.; Knobelsdorf, J. A.; Akanne, H.; Mackenzie, D. R.; Pugsley, T. A.; Zoski, K. T.; Heffner, T. G. \& Wise, L. D. Bioorg. Med. Chem. Lett., 1998, 8, 2067.

22. Gadakh, A.V.; Pandit, C.; Rindhe, S. S. \& Karale, B. K. Bioorg. Med. Chem. Lett., 2010, 2O(18), 5572.

23. Narwade, S. K.; Karale, B. K.; Jagdhani, S. G.; Chaudhari, C. S. \& Rindhe, S.S. Orient. J. Chem., 2008, 24(3), 1029.

24. Akbay, A.; Ören, I.; Arpaci, Ö. T.; Sener E. A. \& Yalçin, I. Arzneimittel-Forsch., 2003, 53, 266.

25. Gong, B. Q.; Hong, F:; Kohm, C.;Bonham, L. \& Klein, P. Bioorg. Med. Chem. Lett., 2004, 14, 1455.

26. Unlu, S.; Baytas, S. N.; Kupeli, E. \& Yesilada, E. Arch Pharm., 2003, 336, 310.

27. Ramalingan, C.; Balasubramanian, S.; Kabilan, S. \& Vasudevan, M. Eur. J. Med. Chem., 2004, 39, 527.

28. Murty, M. S. R.; Ram, K. R.; Rao, R. V.;Yadav, J. S.; Rao, J. V. \& Cheriyan, V.T. J. Med. Chem. Res., 2011, 20, 576. 